\title{
Diacylglycerol Accumulation and Microvascular Abnormalities Induced by Elevated Glucose Levels
}

Bryan A. Wolf,"* Joseph R. Williamson," Richard A. Easom,“ Katherine Chang, "William R. Sherman," and John Turk** ${ }^{*}$ Department of Pathology, ${ }^{\ddagger}$ Division of Laboratory Medicine and Department of Internal Medicine, ${ }^{\$}$ Department of Psychiatry, Washington University School of Medicine, Saint Louis, Missouri 63110

\begin{abstract}
The present experiments were undertaken to examine the hypothesis that glucose-induced increased de novo synthesis of 1,2-diacyl-sn-glycerol (which has been observed in a number of different tissues, including retinal capillary endothelial cells exposed to elevated glucose levels in vitro) and associated activation of protein kinase $\mathbf{C}$ may play a role in mediating glucoseinduced vascular functional changes. We report here that twice daily instillation of $30 \mathrm{mM}$ glucose over $10 \mathrm{~d}$ in a rat skin chamber granulation tissue model induces approximately a 2.7fold increase in diacylglycerol (DAG) levels (versus tissues exposed to $5 \mathrm{mM}$ glucose) in association with marked increases in vascular clearance of albumin and blood flow. The glucose-induced increase in DAG levels as well as the vascular functional changes are prevented by addition of $3 \mathrm{mM}$ pyruvate. Pharmacological activation of protein kinase $C$ with the phorbol ester TPA in the presence of $5 \mathrm{mM}$ glucose increases microvascular albumin clearance and blood flow, and similar effects are observed with 1-monoolein (MOG), a pharmacological inhibitor of the catabolism of endogenous DAG. A pharmacological inhibitor of protein kinase $C$ (staurosporine) greatly attenuates the rise in microvascular albumin clearance (but not the rise in blood flow) induced by glucose or by MOG. These findings are compatible with the hypothesis that elevated concentrations of glucose increase tissue DAG content via de novo synthesis, resulting in protein kinase $C$ activation, and that these biochemical events are among the factors that generate the increased microvascular albumin clearance. (J. Clin. Invest. 1991. 87:31-38.) Key words: diabetes • granulation tissue • angiogenesis • diacylglycerol • protein kinase $\mathbf{C}$
\end{abstract}

\section{Introduction}

Vascular functional changes induced by elevated glucose levels are strongly linked to increased flux of glucose via the sorbitol pathway (1-4). However, the nature of the sorbitol-linked metabolic imbalance(s) which mediate these vascular changes remains unclear $(2,5)$. Elevation of glucose levels has recently been demonstrated to stimulate de novo synthesis of 1,2-diac-

Address reprint requests to John Turk, M.D., Ph.D., Division of Laboratory Medicine, Box 8118, Washington University School of Medicine, 660 South Euclid Ave., St. Louis, MO 63110.

Received for publication 22 February 1990 and in revised form 4 September 1990.

\section{J. Clin. Invest.}

(c) The American Society for Clinical Investigation, Inc.

0021-9738/91/01/0031/08 \$2.00

Volume 87, January 1991, 31-38 yl-sn-glycerol (DAG) $)^{1}$ in a variety of tissues including vascular cells $(6-10)$. Based on evidence linking glucose-induced activation of protein kinase $C$ to increased de novo synthesis of DAG in retinal capillary endothelial cells in vitro, coupled with the pleiotropic effects of protein kinase C and DAG on cellular functions (11), Lee et al. (12) have postulated that increased de novo synthesis of DAG and associated activation of protein kinase $\mathrm{C}$ might play an important role in initiating vascular complications of diabetes. Indeed elevated DAG levels have been reported in the heart, retina, and kidney of diabetic rats (13-15), and protein kinase $\mathrm{C}$ activation has been demonstrated in retina and in glomeruli of diabetic rats as well as in retinal capillary endothelial cells exposed to elevated glucose levels in vitro $(13,14)$.

Williamson et al. have recently described a model in which the microvascular abnormalities induced by elevated glucose concentrations can be examined in skin chamber granulation tissue (16). The microvasculature in such chambers into which 11-30 mM D-glucose has been instilled over several days exhibits two distinct functional changes: increased albumin clearance and increased blood flow (16). These vascular changes are similar to those exhibited by granulation tissue microvasculature from streptozotocin-diabetic rats $(4,17)$. In the present study we have examined $(a)$ whether the glucose-induced functional abnormalities in this model are associated with glucoseinduced DAG accumulation in skin chamber granulation tissue, $(b)$ whether these microvascular functional abnormalities can be prevented by a pharmacological inhibitor of protein kinase $C$, and $(c)$ whether the functional abnormalities can be induced at physiological glucose levels by exogenous activators of protein kinase $\mathrm{C}$ or by inhibitors of the catabolism of endogenous DAG.

\section{Methods}

\section{Materials}

Male Sprague-Dawley rats (250-300 g body weight) were obtained from Sasco (O'Fallon, MO). Rodent chow 5001 was purchased from Ralston Purina Co. (St. Louis, MO). Standard fatty acids were obtained from NuCheck Prep (Elysian, MN). Cardiolipin and 1-oleoyl-2-acetyl$s n$-glycerol (OAG) were obtained from Avanti Polar Lipids Inc. (Birmingham, AL) and octyl- $\beta$-D-glucoside from Calbiochem-Behring Diagnostics (La Jolla, CA). The phorbol ester TPA was purchased from BIOMOL (Plymouth Meeting, PA). Staurosporine was obtained from Kamiya Biochemical Co. (Thousand Oaks, CA). 1-Monoolein (MOG) was purchased from Serdary Research Laboratories (London, Ontario, Canada). Diacylglycerol kinase from Escherichia coli was purchased from Lipidex Inc. (Westfield, NJ). $\left[\gamma-{ }^{32} \mathrm{P}\right]$ ATP $(3,000 \mathrm{Ci} / \mathrm{mmol})$ and

1. Abbreviations used in this paper: DAG, 1,2-diacyl-sn-glycerol; DHAP, dihydroxyacetone phosphate; MOG, 1-mono-oleyl-sn-glycerol; OAG, 1-oleoyl-2-acetyl-sn-glycerol; TMS, trimethylsilyl; TPA, 12-O-tetradecanoylphorbol 13-acetate. 
the liquid scintillation cocktail ACS were purchased from Amersham Corp. (Arlington Heights, IL). 1-Stearoyl-2-[arachidonyl-,6,8,9,11,12,14,15- $\left.{ }^{3} \mathrm{H}(\mathrm{N})\right]$-sn-glycerol was obtained from New England Nuclear (Boston, MA). All organic solvents were obtained from Burdick and Jackson (Muskegon, MI).

\section{Skin chamber insertion}

A modification of the granulation tissue-skin chamber model utilized by Lundberg and Gerdin (18) was employed for these studies (16). In brief, 2-cm circles of skin were removed from the back on either side of the midline (after shaving the hair) of normal nondiabetic rats anesthetized with sodium pentobarbital $(35 \mathrm{mg} / \mathrm{kg})$ injected intraperitoneally. The flanged base of the plastic chamber was then sutured to the skin at the margins of the wound with the skin overlapping the flange to prevent reepithelialization of the granulation tissue inside the chamber and separation of the chamber from the skin by regrowth of hair. New vessels and granulation tissue then form spontaneously on the surface of the exposed fascia inside the chamber. The chambers are equipped with stainless steel screwcaps which are readily removed to permit addition of pharmacological agents to the new vessels as they form inside the chamber. Rats had unlimited access to water and rodent chow throughout the experiment.

\section{Protocol for topical application of reagents to granulation tissue}

10 (or 18) $\mathrm{d}$ after insertion of the chambers, $1.5 \mathrm{ml}$ of Hepes buffer $(25$ mM Hepes pH 7.4, $137 \mathrm{mM} \mathrm{NaCl}, 4.2 \mathrm{mM} \mathrm{KCl}, 3 \mathrm{mM} \mathrm{Na}_{2} \mathrm{HPO}_{4}, 100$ $\mu \mathrm{g} / \mathrm{ml}$ penicillin $\mathrm{G}, 10 \mu \mathrm{g} / \mathrm{ml}$ gentamicin, $2 \%$ polyvinylpyrolidone) supplemented with one or more of the following reagents was added to each chamber: (a) 5 or $30 \mathrm{mM}$ D-glucose; $(b) 1$ or $10 \mu \mathrm{M}$ TPA, which is a phorbol ester activator of protein kinase $\mathrm{C} ;(c) 1$ or $5 \mu \mathrm{M}$ staurosporine, which is an inhibitor of protein kinase $C ;(d) 100$ or $700 \mu \mathrm{M}$ monoolein, which is an inhibitor of DAG kinase; $(e) 3 \mathrm{mM}$ pyruvate; (f) 200 or $625 \mu \mathrm{M}$ 1-oleoyl-2-acetyl-sn-glycerol, which is a membranepermeable analogue of DAG; or $(g) 700 \mu \mathrm{M}$ oleic acid. Solutions were prepared fresh daily from stock solutions. The vehicle DMSO $(0.05 \%)$ was present in each condition. These solutions were added twice daily (9:00 AM and 5:00 PM) for $2 \mathrm{~d}$ or for $10 \mathrm{~d}$ to the chambers. Within an hour of the last treatment, albumin clearance and blood flow were assessed and granulation tissue was removed for quantification of DAG levels.

\section{Measurement of albumin clearance and blood flow of granulation tissue}

Animal preparation. After $10 \mathrm{~d}$ of topical application of the reagents described above, rats were anesthetized with thiopental (Squibb) $(50$ $\mathrm{mg} / \mathrm{kg}$ body weight given intraperitoneally) and the left femoral vein and both iliac arteries were cannulated with polyethylene tubing filled with heparinized saline. The femoral vein cannula was used for tracer injection. The right iliac artery cannula was connected to a Statham P50 pressure transducer for monitoring blood pressure as well as for arterial blood sampling, and the left iliac artery cannula was connected to a withdrawal pump for assessment of regional blood flow. The trachea also was cannulated and connected to a small rodent respirator for continuous ventilatory support.

Preparation of radiolabeled tracers. ${ }^{125} \mathrm{I}-\mathrm{BSA}$ and ${ }^{131} \mathrm{I}-\mathrm{BSA}$ were prepared by iodinating $1 \mathrm{mg}$ of purified, monomeric BSA with $1 \mathrm{mCi}$ of ${ }^{125}$ I or ${ }^{131}$ I (NEN Research Products, Boston, MA) with iodogen (Pierce Chemical Co., Rockford, IL) (19).

Measurement of albumin clearance and blood flow. Two different radiolabeled albumins $\left({ }^{131} \mathrm{I}\right.$ and $\left.{ }^{125} \mathrm{I}\right)$ were used to measure albumin clearance (20). ${ }^{131}$ I-BSA was the primary (or permeating) tracer and was allowed to circulate for $10 \mathrm{~min}$. ${ }^{125} \mathrm{I}$-BSA was used as the intravascular space tracer (to correct tissue ${ }^{131}$ I-BSA activity for intravascular tracer) and was allowed to circulate for only $2 \mathrm{~min}$ (the assumption is that relatively little tracer permeates the vasculature during this time). Vascular clearance of plasma ${ }^{131}$ I-BSA is expressed as nanoliters plas$\mathrm{ma} \cdot$ gram wet weight ${ }^{-1} \cdot \mathrm{min}^{-1}$.
Blood flow (expressed as milliliters blood $\cdot$ gram wet weight $^{-1}$. $\min ^{-1}$ ) was measured by injecting $15 \mu \mathrm{m}{ }^{85} \mathrm{Sr}$-microspheres (NEN Research Products) as described in previous publications $(20,21)$.

\section{Measurement of DAG content of granulation tissue}

Extraction of DAG from granulation tissue. Granulation tissue was stored at $-70^{\circ} \mathrm{C}(<72 \mathrm{~h})$ until extraction. Frozen granulation tissue was pulverized in a percussion mill on dry ice. The powdered tissue was transferred to a silanized $16 \times 100$ borosilicate tube. Internal standard (100,000-200,000 dpm of 1-stearoyl-2-[ $\left.{ }^{3} \mathrm{H}_{8}\right]$-arachidonyl-sn-glycerol) was added to each tube. Each tube then received $\mathrm{H}_{2} \mathrm{O}(0.5 \mathrm{ml})$ and chloroform/methanol $(4.5 \mathrm{ml}$ of a $1: 2$ solution $(\mathrm{vol} / \mathrm{vol})$ with $0.05 \%$ butylated hydroxytoluene). Tubes were then sonicated $60 \mathrm{~min}$ in a water bath and vortexed $1 \mathrm{~min}$. Water $(2 \mathrm{ml})$ was then added. The tubes were vortexed $(1 \mathrm{~min})$ and then centrifuged $(5 \mathrm{~min}$ at $900 \mathrm{~g}$ ). The lower organic phase was transferred to a silanized $10 \mathrm{ml}$ disposable borosilicate conical tube. The aqueous phase was reextracted with chloroform/ methanol $(2 \mathrm{ml})$, chloroform $(1 \mathrm{ml})$, and water $(2 \mathrm{ml})$, and was centrifuged. The lower (organic) phase was combined with that from the first extraction. The organic phase was washed with water $(1 \mathrm{ml})$, and the aqueous phase was saved for determination of its protein content. The organic phase was evaporated under $\mathrm{N}_{2}$, reconstituted with chloroform/methanol $(0.5 \mathrm{ml})$, evaporated again, and then reconstituted in $0.05 \mathrm{ml}$ of chloroform.

Enzymatic measurement of DAG mass. DAG mass was measured by an enzymatic assay employing diacylglycerol kinase from $E$. coli to phosphorylate DAG to [ $\left.{ }^{32} \mathrm{P}\right]$ phosphatidic acid which was then quantitated as previously described (22) with modifications as specified elsewhere (10). We have previously shown that under our conditions the modified assay is linear from 100 pmol to the low nanomolar range (10). Furthermore, the mass of DAG measured by this modified enzymatic assay shows an excellent correspondence with the mass of DAG measured by gas chromatographic-negative ion-chemical ionizationmass spectrometric determination of its fatty acyl content (23).

Measurement of protein content of granulation tissue. The aqueous phase obtained from the extraction of DAG from granulation tissue was lyophilized and incubated $60 \mathrm{~min}$ at $37^{\circ} \mathrm{C}$ in $5 \mathrm{ml}$ of $\mathrm{NaOH}(1 \mathrm{~N})$. An aliquot was then taken for protein determination using the bicinchoninic acid assay kit (Sigma Chemical Co., St. Louis, MO) (24).

\section{Measurement of sorbitol and myo-inositol content of granulation tissue}

Tissue sorbitol and myo-inositol content were measured by an electron ionization gas chromatographic-mass spectrometric method as their butylboronate derivatives as previously described (25).

\section{Protein kinase $C$ activity measurements}

Protein kinase $\mathrm{C}$ activity was measured essentially as described elsewhere (26). In brief, excised granulation tissue was minced and homogenized with a Tissue-Tearor (Biospec Products, Bartlesville, OK) in $1 \mathrm{ml}$ of ice-cold buffer (25 mM-Tes/NaOH [pH 7.4]/1 mM-EGTA/0.5 mMdithiothreitol $/ 1 \mathrm{mM}-\mathrm{PMSF} / 100 \mu \mathrm{g}$ of leupeptin $/ \mathrm{ml}$ ). The homogenate was centrifuged $\left(2,000 \mathrm{rpm}, 5 \mathrm{~min}, 4^{\circ} \mathrm{C}\right)$ to remove cell debris, and the supernatant was ultracentrifuged $\left(135,000 \mathrm{~g}, 60 \mathrm{~min}, 4^{\circ} \mathrm{C}\right)$. The supernatant from this last step (cytosolic fraction) was removed, and the pellet (particulate fraction) was washed and resuspended in homogenization buffer (as above) with sonication ( $5 \mathrm{~s}$, setting 2 , Branson Cell Disruptor, Danbury, CT) on ice. Triton X-100 was then added to cytosolic and particulate fractions (final concentration $0.1 \%$ ), and the sample was sonicated on ice for $45-60 \mathrm{~min}$. The samples were clarified by centrifugation $\left(13,000 \mathrm{~g}, 15 \mathrm{~min}, 4^{\circ} \mathrm{C}\right)$ before assay.

Protein kinase $C$ activity in cytosol $(5-10 \mu \mathrm{l})$ and particulate (5-10 $\mu l)$ fractions was assayed by incorporation of $\left[{ }^{32} \mathrm{P}\right] \mathrm{P}_{\mathrm{i}}$ from $\left[\gamma^{-32} \mathrm{P}\right]-\mathrm{ATP}$ into histone III-S at $30^{\circ} \mathrm{C}$. The total assay volume was $100 \mu \mathrm{l}$, and the assay medium contained $100 \mathrm{mM}-\mathrm{Tes} / \mathrm{NaOH}(\mathrm{pH} 7.4), 5 \mathrm{mM}-\mathrm{MgCl}_{2}$, $1 \mathrm{mM}-E G T A, 400 \mu \mathrm{g}$ of histone III-S/ml, with or without $1.3 \mathrm{mM}-\mathrm{Ca}^{2+}$ (free $\mathrm{Ca}^{2+}$ concentration $\approx 300 \mu \mathrm{M}$ ), with or without $125 \mu \mathrm{g}$ of phos- 
phatidylserine/ml, and with or without 1,2-diolein (when added, 2.4 $\mu \mathrm{g} / \mathrm{ml}$ ). After a preincubation period of $2 \mathrm{~min}$, the reaction was initiated by the addition of $10 \mu \mathrm{l}$ of $\left[\gamma^{32} \mathrm{P}\right]-\mathrm{ATP}$ (final concentration 20 $\mu \mathrm{M}, \approx 1.4 \mu \mathrm{Ci} /$ tube). After $30 \mathrm{~s}, 50 \mu$ l of stop buffer (186 mM-Tris/ $\mathrm{HCl}$ (pH 6.7)/9 mM-SDS/6 mM-2-mercaptoethanol/15\% glycerol) was added and protein was denatured by boiling for $2 \mathrm{~min}$. Phosphorylated histone bands $(120 \mu \mathrm{l})$ were separated from endogenous proteins by SDS/PAGE in $12 \%$ gels. After staining with Coomassie blue $(0.1 \%$ Coomassie blue R-250 in 10\% [vol/vol] acetic acid), the three histone bands of highest molecular mass (accounting for $\approx 95 \%$ of histone radioactivity) were excised from the gel and treated with $1.0 \mathrm{ml}$ of protosol. The ${ }^{32} \mathrm{P}$ content was determined by liquid scintillation spectrometry.

Protein kinase $\mathrm{C}$ activity was calculated after the subtraction of $\left.{ }^{32} \mathrm{P}\right] \mathrm{P}_{1}$ incorporation into histone in the absence of $\mathrm{Ca}^{2+}$, phosphatidylserine or diacylglycerol (basal activity). The inclusion of these cofactors resulted in a two-to-threefold and seven-to-eightfold stimulation of "basal" histone phosphorylation in the particulate and cytosol fractions derived from islets, respectively. Protein kinase C-catalysed incorporation of $\left[{ }^{32} \mathrm{P}\right] \mathrm{P}_{\mathrm{i}}$ into histone III-S was found to be linear with time and with protein concentration over the course of the assay period. Activity was normalized to the protein content of the cytosol or membrane fraction determined as described above.

\section{Statistical analysis}

Results are shown as mean $\pm \mathrm{SE}$ and were analyzed either by one-way or two-way ANOVA: albumin clearance, blood flow, and DAG content were considered the dependent variables in the ANOVA while the various treatments were independent variables. If the ANOVA indicated the presence of a statistically significant effect of treatment $(P$ $<0.05$ ), differences between the means within the treatment group were analyzed by a two-tailed $t$ test using the residual variance estimate from the ANOVA: a $P<0.05$ was considered statistically significant.

\section{Results}

Effect of elevated glucose concentrations on microvascular albumin clearance and blood flow and on the DAG content of granulation tissue. As illustrated in Fig. 1, instillation of an elevated concentration ( $30 \mathrm{mM}$ ) of D-glucose into granulation tissue skin chambers twice daily for $10 \mathrm{~d}$ induced nearly a fourfold rise in microvascular permeation of albumin (clearance $480 \pm 72$ vs. $125 \pm 10 \mathrm{nl} \cdot \mathrm{g}$ wet $\left.\mathrm{wt}^{-1} \cdot \mathrm{min}^{-1}, P<0.001\right)$ and a 1.7 -fold increase in blood flow $(0.83 \pm 0.02 \mathrm{vs} .0 .48 \pm 0.02 \mathrm{ml} \cdot \mathrm{g}$ wet $\left.^{-1} \cdot \mathrm{min}^{-1}, P<0.001\right)$ compared to instillation of a physio- logical concentration $(5 \mathrm{mM})$ of D-glucose. In association with these functional microvascular changes, the elevated concentration of D-glucose also induced a 2.7 -fold increase in the DAG mass of the granulation tissue (Fig. $1 \mathrm{C}, P<0.05$ vs. 5 $\mathrm{mM}$ D-glucose control). As summarized in Table $\mathrm{I}$, instillation of $30 \mathrm{mM}$ glucose into granulation tissue skin chambers for only $2 \mathrm{~d}$, rather than $10 \mathrm{~d}$, induced no change in microvascular albumin permeability and only a modest rise in tissue diacylglycerol content, which did not achieve statistical significance. By contrast, the glucose-induced rise in blood flow was essentially fully developed by $2 \mathrm{~d}$. This suggests that the rise in blood flow induced by glucose may occur by a mechanism different from that responsible for the increase in albumin permeability and that only the latter phenomenon is temporally associated with diacylglycerol accumulation.

Coadministration of $3 \mathrm{mM}$ pyruvate with $30 \mathrm{mM}$ D-glucose totally prevented the rise in DAG content induced by the periodic instillation of $30 \mathrm{mM}$ D-glucose for $10 \mathrm{~d}$ (Fig. $1 \mathrm{C}$ ). Pyruvate also totally prevented the glucose-induced rise in microvascular albumin clearance after $10 \mathrm{~d}$ (Fig. $1 \mathrm{~A}$ ) but blocked the rise in blood flow by only $50 \%$ (Fig. $1 \mathrm{~B}$ ). These observations suggested that the rise in DAG content induced by glucose over $10 \mathrm{~d}$ might be functionally connected to the glucose-induced increment in microvascular albumin clearance, possibly via activation of protein kinase $C$. This possibility was further examined with pharmacological modulators of protein kinase $C$ activity.

Effects of pharmacological activation of protein kinase $C$ at physiological glucose concentrations on microvascular albumin clearance and blood flow in granulation tissue. The phorbol ester TPA is a recognized activator of protein kinase $C$ and binds at the DAG site on the enzyme (11). As illustrated in Fig. 2 , when coadministered with a physiological concentration ( 5 $\mathrm{mM})$ of D-glucose, TPA $(10 \mu \mathrm{M})$ was found to induce a rise in microvascular albumin clearance to a value nearly as great as that achieved with $30 \mathrm{mM}$ glucose alone and significantly greater than that achieved by $5 \mathrm{mM}$ glucose alone (Fig. $2 \mathrm{~A}$ ). TPA $(10 \mu \mathrm{M})$ also induced a rise in blood flow in the skin chamber granulation tissue to a value roughly half as great as that achieved by $30 \mathrm{mM}$ glucose alone but still significantly greater than that of $5 \mathrm{mM}$ glucose alone (Fig. 2 B). TPA did not influence the DAG content of granulation tissue (ratio of $1.23 \pm 0.41$ compared to $5 \mathrm{mM}$ glucose control).

Table I. Effect of $30 \mathrm{mM}$ Glucose on Albumin Clearance, Blood Flow, and Diacylglycerol Content after 2 d of Periodic Instillation

\begin{tabular}{|c|c|c|c|c|}
\hline \multirow[t]{2}{*}{ Condition } & & Blood flow & Albumin permeability & $\begin{array}{l}\text { Diacylglycerol } \\
\text { content }\end{array}$ \\
\hline & & $m l \cdot(g \text { wet } w t)^{-1} \cdot \mathrm{min}^{-1}$ & $n l \cdot(g \text { wet wt })^{-1} \cdot \min ^{-1}$ & nmol/mg protein \\
\hline $5 \mathrm{mM}$ glucose & Mean & 0.42 & 139 & 0.48 \\
\hline \multirow[t]{2}{*}{$(2 \mathrm{~d})$} & SD & \pm 0.05 & \pm 33 & \pm 0.04 \\
\hline & $n$ & 7 & 7 & 5 \\
\hline $30 \mathrm{mM}$ glucose & Mean & 0.76 & 116 & 0.67 \\
\hline \multirow[t]{2}{*}{$(2 \mathrm{~d})$} & SD & \pm 0.09 & \pm 46 & \pm 0.37 \\
\hline & $n$ & 6 & 7 & 7 \\
\hline$P$ value & & $<0.001$ & NS & NS \\
\hline
\end{tabular}

Granulation tissue formation was induced in bilateral skin chambers in nondiabetic male rats as described in the legend of Fig. 1. Beginning $18 \mathrm{~d}$ after implantation of the chambers, $1.5 \mathrm{ml}$ of Hepes buffer supplemented with $5 \mathrm{mM}$ or with $30 \mathrm{mM}$ D-glucose was added to the granulation tissue in the test chamber twice daily for another $2 \mathrm{~d}$. At the end of the treatment period, albumin clearance (measured with ${ }^{131} \mathrm{I}-\mathrm{BSA}$ and ${ }^{125} \mathrm{I}-$ BSA), blood flow (measured with ${ }^{85} \mathrm{Sr}$-microspheres), and DAG content (measured enzymatically) were determined as described in Methods. 

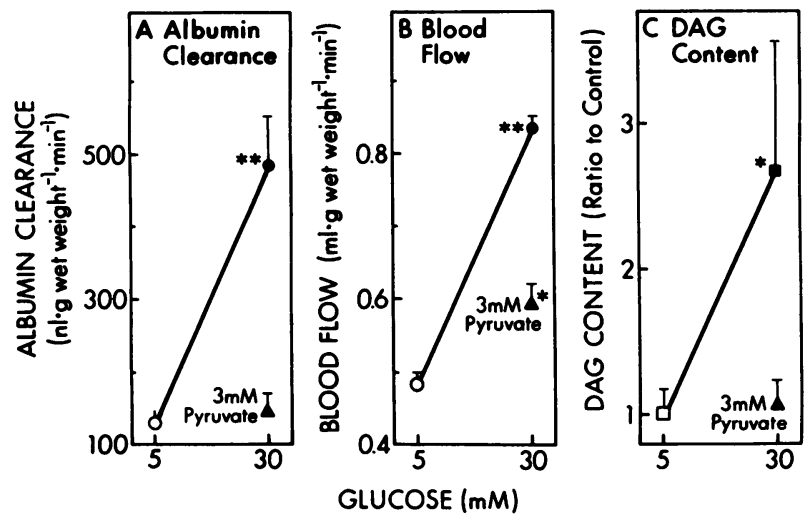

Figure 1. Effect of glucose on albumin clearance, blood flow, and DAG content of granulation tissue from skin chambers. Granulation tissue formation was induced in bilateral skin chambers in normal nondiabetic male rats by removal of 2-cm circles of skin on either side of the midline of the back. The flanged base of a plastic chamber was then sutured to the skin at the margins of the wound with the skin overlapping the flange to prevent reepithelialization of the granulation tissue inside the chamber and separation of the chamber from the skin by regrowth of hair. New vessels and granulation tissue then form spontaneously on the surface of the exposed fascia inside the chamber. Beginning $10 \mathrm{~d}$ later, $1.5 \mathrm{ml}$ of Hepes buffer supplemented with 5 or $30 \mathrm{mM}$ D-glucose was added to the granulation tissue in the test chamber twice daily for another $10 \mathrm{~d}$. At the end of the treatment period, albumin clearance (measured with ${ }^{131}$ I-BSA and ${ }^{125} \mathrm{I}-\mathrm{BSA}$ ), blood flow (measured with ${ }^{85} \mathrm{Sr}$-microspheres), and DAG content (measured enzymatically) were determined as detailed in Methods. Results are shown as the mean $\pm \mathrm{SE}$ of albumin clearance (nanoliters $\cdot$ grams wet weight ${ }^{-1} \cdot \min ^{-1}[A]$ ), blood flow (milliliters $\cdot$ grams wet weight ${ }^{-1} \cdot \min ^{-1}[B]$ ) and DAG content (expressed as ratio to $5 \mathrm{mM}$ glucose, $[C]$ ) from $9-10$ observations per condition. The effect of $3 \mathrm{mM}$ pyruvate is shown by the solid triangles $(n=5)$. DAG content of granulation tissue exposed to $5 \mathrm{mM}$ glucose was $0.63 \pm 0.15 \mathrm{pmol} \mathrm{DAG} / \mu \mathrm{g}$ protein. *Significantly different from $5 \mathrm{mM}$ glucose control, $P<0.05$ (ANOVA of DAG data was performed on natural logarithm-transformed data). ${ }^{* *}$ Significantly different from $5 \mathrm{mM}$ glucose control, $P<0.001$.

At a concentration of $1 \mu \mathrm{M}$, TPA exerted relatively little influence on microvascular permeability to albumin, although it did increase blood flow significantly to a level $\sim 50 \%$ of that induced by $30 \mathrm{mM}$ glucose (Fig. $2 \mathrm{~A}$ ). Similarly, $1 \mu \mathrm{M}$ TPA did not influence the cytosolic to membrane distribution of protein kinase $\mathrm{C}$ enzymatic activity in granulation tissue, as illustrated in Fig. 3, although $10 \mu \mathrm{M}$ TPA did induce the translocation of protein kinase $C$ enzymatic activity from cytosol to membrane. Thus, the increase in microvascular albumin permeability and the translocation of protein kinase $\mathrm{C}$ exhibit similar relationships to the concentration of TPA. These observations indicated that pharmacological activation of protein kinase $C \mathrm{mim}$ icked almost completely the effect of elevated glucose concentrations on microvascular albumin clearance and partially reproduced the effect on blood flow. This is consistent with a role for protein kinase $C$ activation in mediating some effects of glucose on microvascular functional parameters.

The fact that glucose itself did not induce demonstrable translocation of protein kinase $\mathrm{C}$ activity in granulation tissue (Fig. 3) may reflect the cellular heterogeneity of the tissue and the fact that the microvascular functional changes induced by glucose are mediated by changes in protein kinase $\mathrm{C}$ activity in

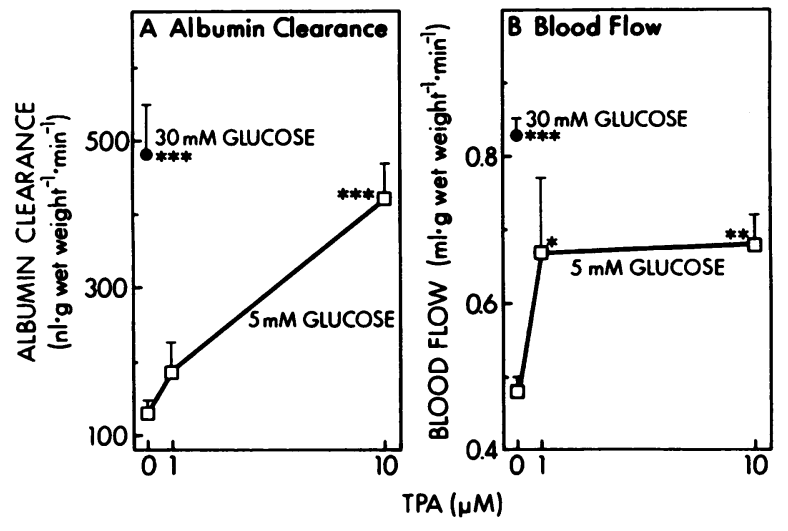

Figure 2. Effect of TPA, a protein kinase $\mathrm{C}$ activator, on albumin clearance and blood flow in granulation tissue from skin chambers exposed to $5 \mathrm{mM}$ D-glucose. Granulation tissue formation was induced as described in Fig. 1 and Methods. Granulation tissue in skin chambers received twice daily $1.5 \mathrm{ml}$ of Hepes buffer supplemented with 1 or $10 \mu \mathrm{M}$ TPA and $5 \mathrm{mM}$ D-glucose for $10 \mathrm{~d}$. Albumin clearance and blood flow of granulation tissue were then determined as described in Methods. Results are shown as the mean $\pm \mathrm{SE}$ of albumin clearance $(A$, nanoliters $\cdot \mathrm{gram}$ wet weight ${ }^{-1} \cdot \min ^{-1}$ of $5 \mathrm{mM}$ D-glucose +0 to $10 \mu \mathrm{M}$ TPA [-], and $30 \mathrm{mM}$ D-glucose [0]) and blood flow ( $B$, milliliters - gram wet weight ${ }^{-1} \cdot \min ^{-1}$ at $5 \mathrm{mM}$ D-glucose +0 to $10 \mu \mathrm{M}$ TPA [-], and $30 \mathrm{mM}$ D-glucose [0]) from 3-10 observations per condition. *Significantly different from $5 \mathrm{mM}$ glucose control, $P=0.011$. ** Significantly different from $5 \mathrm{mM}$ glucose control, $P=0.001$. *** Significantly different from $5 \mathrm{mM}$ glucose control, $P<0.001$.

a quantitatively minor subpopulation of cells within the tissue, such as vascular endothelial cells. Fibroblasts and macrophages are probably the most abundant cell types in the granulation tissue, and their protein kinase $\mathrm{C}$ activity may be both insensitive to glucose and uninvolved in the microvascular functional changes. This hypothesis was tested by examining the effects of

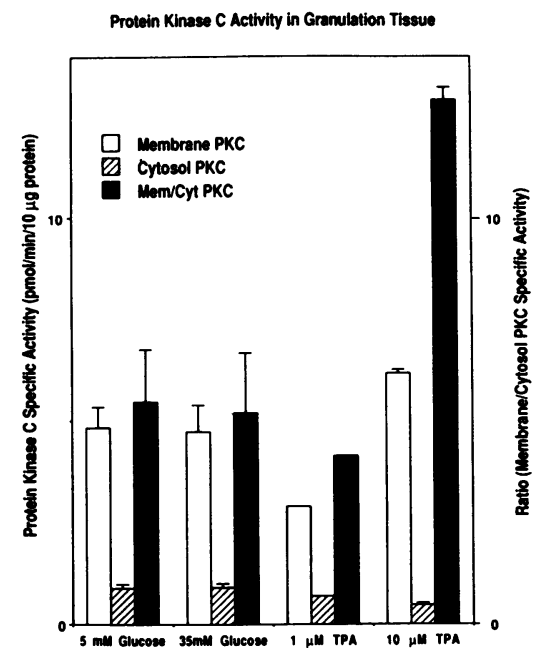

Figure 3. Translocation of protein kinase $\mathrm{C}$ enzymatic activity from cytosol to membrane in granulation tissue induced by TPA. Granulation tissue formation was induced as described in the legend of Fig. 1. Granulation tissue in skin chambers received twice daily $1.5 \mathrm{ml}$ of Hepes buffer supplemented with 5 $\mathrm{mM}$ or $30 \mathrm{mM}$ Dglucose; $0 \mu \mathrm{M}, 1 \mu \mathrm{M}$, or $10 \mu \mathrm{M} \mathrm{TPA}$; and 0 or $3 \mathrm{mM}$ pyruvate. These additions were continued twice daily for $10 \mathrm{~d}$. At the end of this period, granulation tissue was excised and homogenized, and the protein kinase $\mathrm{C}$ activity in the membrane and cytosol fractions was determined as described in Methods. Protein kinase $\mathrm{C}$ specific activity was calculated by dividing total activity in the membrane or cytosol fraction by the measured protein content of that fraction. 
pharmacologic inhibitors of protein kinase $\mathrm{C}$ on glucose-induced microvascular functional changes.

Effect of pharmacological inhibition of protein kinase $C$ on the microvascular functional changes induced by elevated concentrations of D-glucose. Staurosporine is a potent inhibitor of protein kinase $C$ which has been widely employed to evaluate the potential involvement of protein kinase $C$ in physiological events $(26,27)$. As illustrated in Fig. 4 , staurosporine $(5 \mu \mathrm{M})$ did not significantly influence microvascular albumin clearance (Fig. 4 A) or blood flow (Fig. 4 B) when coadministered with a physiological concentration $(5 \mathrm{mM})$ of D-glucose over a $10-d$ period in the granulation tissue skin chambers. Staurosporine also did not significantly influence the effect of an elevated concentration $(30 \mathrm{mM})$ of D-glucose to induce a rise in blood flow (Fig. 4 B) and did not influence the granulation tissue DAG content (ratio $1.6 \pm 0.39$ compared to control at 30 $\mathrm{mM}$ glucose and ratio of $1.40 \pm 0.25$ at $5 \mathrm{mM}$ glucose).

Staurosporine did substantially reduce (by $65 \%$ ) the increase in microvascular albumin clearance induced by $30 \mathrm{mM}$ glucose (Fig. $4 \mathrm{~A}, P=0.0012$ ). These observations are consistent with the hypothesis that activation of protein kinase $\mathrm{C}$ mediates the increase in microvascular albumin clearance induced by glucose. This activation may be effected by the glucose-induced rise in endogenous DAG demonstrated in Fig. 1 C. This possibility was further explored with a pharmacological inhibitor of the catabolism of endogenous DAG.

Effects of a pharmacological inhibitor of DAG kinase on microvascular albumin clearance and blood flow. The compound 1-mono-oleoyl-sn-glycerol (MOG) is an inhibitor of the enzyme (DAG kinase) which converts DAG to phosphatidic acid (28). MOG has been used as a pharmacological tool to

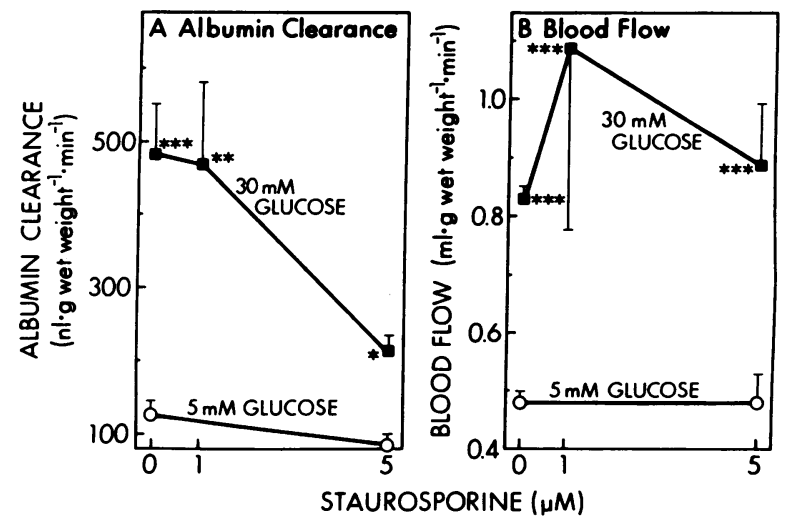

Figure 4. Effect of staurosporine, a protein kinase $\mathrm{C}$ inhibitor, on albumin clearance and blood flow in granulation tissue from skin chambers exposed to 5 or $30 \mathrm{mM}$ D-glucose. Granulation tissue formation was induced as described in Fig. 1 and Methods. Granulation tissue in skin chambers received twice daily $1.5 \mathrm{ml}$ of Hepes buffer supplemented with 1 or $5 \mu \mathrm{M}$ staurosporine and 5 or $30 \mathrm{mM}$ D-glucose for $10 \mathrm{~d}$. Albumin clearance and blood flow of granulation tissue were then determined as described in Methods. Results are shown as the mean \pm SE of albumin clearance $(A$, nanoliters $\cdot$ gram wet weight ${ }^{-1} \cdot \mathrm{min}^{-1}$ at $5 \mathrm{mM}$ D-glucose [O and $30 \mathrm{mM}$ D-glucose $[-])$ and blood flow $(B$, milliliters $\cdot$ gram wet weight ${ }^{-1} \cdot \mathrm{min}^{-1}$ at $5 \mathrm{mM}$ D-glucose [O- - ] and $30 \mathrm{mM}$ Dglucose $[-]$ ) from $2-10$ observations per condition. *Significantly different from $5 \mathrm{mM}$ glucose $+5 \mu \mathrm{M}$ staurosporine, $P=0.05$. **Significantly different from $5 \mathrm{mM}$ glucose control, $P<0.01$. *** Significantly different from $5 \mathrm{mM}$ glucose control, $P<0.001$.

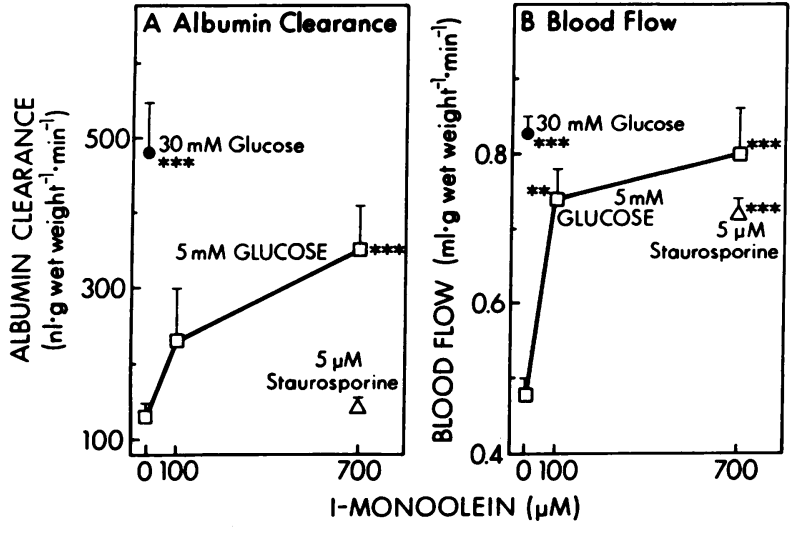

Figure 5. Effect of monoolein, an inhibitor of DAG metabolism, on albumin clearance and blood flow in granulation tissue from skin chambers exposed to $5 \mathrm{mM}$ D-glucose. Granulation tissue formation was induced as described in Fig. 1 and Methods. Granulation tissue in skin chambers received twice daily $1.5 \mathrm{ml}$ of Hepes buffer supplemented with 100 or $700 \mu \mathrm{M} 1$-monoolein and/or $5 \mu \mathrm{M}$ staurosporine and $5 \mathrm{mM}$ D-glucose for $10 \mathrm{~d}$. At the end of the treatment period, albumin clearance and blood flow of granulation tissue were then determined as described in Methods. Results are shown as the mean $\pm \mathrm{SE}$ of albumin clearance $(A$, nanoliters · gram wet weight ${ }^{-1} \cdot \min ^{-1}$ at $5 \mathrm{mM}$ D-glucose +0 to $700 \mu \mathrm{M}$ monoolein $[-], 30 \mathrm{mM}$ D-glucose alone [o], and $5 \mathrm{mM}$ D-glucose $+700 \mu \mathrm{M}$ monoolein $+5 \mu \mathrm{M}$ staurosporine $[\Delta])$ and blood flow $(B$, milliliters $\cdot$ gram wet weight ${ }^{-1}$ at $5 \mathrm{mM}$ D-glucose +0 to $700 \mu \mathrm{M}$ monoolein [-], $30 \mathrm{mM}$ D-glucose alone [o], and $5 \mathrm{mM}$ D-glucose $+700 \mu \mathrm{M}$ monoolein $+5 \mu \mathrm{M}$ staurosporine $[\Delta])$ from $2-10$ observations per condition. ${ }^{* *}$ Significantly different from $5 \mathrm{mM}$ glucose control, $P<0.01{ }^{* * *}$ Significantly different from $5 \mathrm{mM}$ glucose control, $P<0.001$.

impair the catabolism of endogenous DAG and to augment its accumulation $(23,28)$. As illustrated in Fig. $5 \mathrm{~A}$, when coadministered with a physiological concentration $(5 \mathrm{mM})$ of glucose, MOG induced a substantial rise in microvascular albumin clearance to a value two-thirds of that achieved by $30 \mathrm{mM}$ glucose and nearly threefold higher than that observed with instillation of $5 \mathrm{mM}$ glucose alone. The MOG-induced rise in albumin clearance was essentially completely prevented by the protein kinase $C$ inhibitor staurosporine, which is compatible with the hypothesis that the effect of MOG is mediated by accumulation of endogenous DAG and activation of protein kinase C. As illustrated in Fig. 5 B, MOG also induced a rise in blood flow when coadministered with $5 \mathrm{mM}$ glucose to a value essentially identical to that achieved by $30 \mathrm{mM}$ glucose. The effect of MOG to increase blood flow was little affected by staurosporine, however, indicating that this event may be independent of protein kinase $C$ activation. The DAG content of granulation tissue was not demonstrably altered by MOG (ratio $1.17 \pm 0.13$ compared to $5 \mathrm{mM}$ glucose control) at the time of assay, although transient elevation of DAG causing sustained activation of protein kinase $C$ cannot be excluded. Neither oleic acid $(700 \mu \mathrm{M})$ nor 1-oleoyl-2-acetyl-sn-glycerol (200 $\mu \mathrm{M}$ or $625 \mu \mathrm{M})$ mimicked the effects of MOG on albumin clearance or blood flow (not shown).

Sorbitol and myo-inositol content of granulation tissue. The sorbitol and myo-inositol contents of granulation tissue from skin chambers exposed to various treatments are shown in Table II. Myo-inositol content was not affected by any of the 
Table II. Effects of Protein Kinase C Activator and Inhibitor and DAG Analogues on Sorbitol and Myo-Inositol Content of Granulation Tissue from Skin Chambers Exposed to 5 or $30 \mathrm{mM}$ D-Glucose

\begin{tabular}{ccc}
\hline Group & Sorbitol & Myo-Inositol \\
\hline & \multicolumn{2}{c}{ nmol/g tissue } \\
$5 \mathrm{mM}$ glucose (6)* & $1.9 \pm 0.8$ & $467 \pm 75$ \\
$+10 \mu \mathrm{M}$ TPA (8) & $4.5 \pm 2.6^{\ddagger}$ & $563 \pm 147$ \\
$+5 \mu \mathrm{M}$ staurosporine (6) & $2.0 \pm 1.4$ & $491 \pm 90$ \\
$+700 \mu \mathrm{M}$ monoolein (6) & $2.4 \pm 2.0$ & $476 \pm 76$ \\
$+700 \mu \mathrm{M}$ monoolein $+5 \mu \mathrm{M}$ & & \\
staurosporine (7) & $2.3 \pm 1.7$ & $480 \pm 65$ \\
$+700 \mu \mathrm{M}$ oleic acid (4) & $2.3 \pm 1.5$ & $523 \pm 77$ \\
$+625 \mu \mathrm{M}$ OAG (2) & $7.4 \pm 3.9^{\ddagger}$ & $586 \pm 31$ \\
$30 \mathrm{mM}$ glucose (6) & $23.7 \pm 4.4^{\S}$ & $500 \pm 99$ \\
$+5 \mu \mathrm{M}$ staurosporine (6) & $27.5 \pm 5.2^{\S}$ & $522 \pm 88$ \\
$+3 \mathrm{mM}$ pyruvate (5) & $11.4 \pm 4.6^{\|}$ & $404 \pm 50$
\end{tabular}

Granulation tissue forming in tissue chambers of nondiabetic rats was treated for $10 \mathrm{~d}$ with 5 or $30 \mathrm{mM}$ D-glucose supplemented with staurosporine (an inhibitor of protein kinase C), monoolein (an inhibitor of DAG, metabolism), TPA (a phorbol ester activator of protein kinase C), OAG (a membrane-permeable DAG analogue) or pyruvate. Granulation tissue was then harvested and its sorbitol and myo-inositol content determined as described in Methods. Results are shown as the mean $\pm \mathrm{SD}$ of sorbitol and myo-inositol content expressed as nanomoles per gram wet weight of tissue.

* No. of animals in parentheses.

₹ Significantly different from $5 \mathrm{mM}$ glucose at $P<0.05$.

${ }^{8}$ Significantly different from $5 \mathrm{mM}$ glucose at $P<0.001$.

" Significantly different from $30 \mathrm{mM}$ glucose control at $P<0.005$.

pharmacological manipulations described above. Glucose (30 min) caused a 13-fold increase in sorbitol levels $(P<0.001)$ which was reduced by $50 \%$ by $3 \mathrm{mM}$ pyruvate. Treatment of granulation tissue with staurosporine, monoolein, and oleic acid had no effect on sorbitol content (Table II). Sorbitol levels were slightly elevated in tissues exposed to TPA and DAG.

\section{Discussion}

Previous work has established that periodic instillation of high concentrations of glucose into skin chambers induces functional abnormalities in the granulation tissue microvasculature in these chambers, including increased albumin clearance and increased blood flow (16). This study confirms these findings and establishes that high glucose concentrations also induce accumulation of DAG in skin chamber granulation tissue. The elevated levels of DAG are consistent with evidence of elevation of DAG levels and of increased de novo synthesis of DAG in a variety of tissues exposed to elevated glucose levels in vitro (6-10) as well as in the heart, retina, and kidney of diabetic rats $(12,14,15)$.

De novo synthesis of DAG from dihydroxyacetone phosphate (DHAP) may occur by two pathways. One involves direct acylation of DHAP followed by reduction at carbon two (by NADPH). The resulting lysophosphatidic acid is then further acylated to form phosphatidic acid which is then dephosphorylated to yield DAG. The other involves reduction of DHAP to glycerol-3-phosphate (by NADH) which is then acyl- ated to form lysophosphatidic acid, etc., as in the first pathway. The latter pathway would be favored by increased metabolism of glucose via the sorbitol pathway which has been shown in the lens to increase the NADH:NAD ${ }^{+}$ratio more than the NADPH:NADP ${ }^{+}$ratio (29).

The likelihood that the elevated levels of DAG in the present experiments reflect increased de novo synthesis of DAG is suggested by evidence that in granulation tissue incubated in $50 \mathrm{mM}$ vs. $5 \mathrm{mM}$ glucose in vitro, triose phosphate levels are significantly increased (29a). This increase in triose phosphate levels, like the increase in DAG levels in the present experiments, is completely prevented by the addition of pyruvate.

While the biochemical mechanism(s) whereby exogenous pyruvate prevents the glucose-induced rise in DAG is not completely established, its effects appear to be linked to normalization of the NAD ${ }^{+}: \mathrm{NADH}$ ratio which is decreased by accelerated oxidation of sorbitol to fructose in tissues exposed to high glucose levels. Exogenous pyruvate has also been shown to prevent glucose-induced rises in triose phosphates in red cells, presumably by accelerating oxidation of glyceraldehyde-3-phosphate to glycerate-1,3-biphosphate (30). The latter reaction requires $\mathrm{NAD}^{+}$which is generated during reduction of pyruvate to lactate. Because the triose phosphates (fructose diphosphate, DHAP, and glyceraldehyde-3-phosphate) are in equilibrium, exogenous pyruvate reduces triose phosphate levels by stimulating their catabolism. The oxidation of $\mathrm{NADH}$ to $\mathrm{NAD}^{+}$by pyruvate also decreases the availability of NADH required for reduction of DHAP to glycerol-3-phosphate.

The likelihood that NADH is increased in granulation tissue exposed to elevated glucose levels is also supported by studies of Kawamura et al. (29a) demonstrating increases in the ratio of lactate/pyruvate and fructose/sorbitol. Thus the effects of exogenous pyruvate on DAG synthesis are twofold: $(a)$ it reduces substrate levels (DHAP), and $(b)$ it reduces the availability of the co-factor (NADH) needed for reduction of DHAP to glycerol-3-phosphate. The $\sim 50 \%$ reduction in tissue sorbitol levels by pyruvate also is consistent with a pyruvate-induced increase in the $\mathrm{NAD}^{+}: \mathrm{NADH}$ ratio, i.e., the increased availability of $\mathrm{NAD}^{+}$would stimulate oxidation of sorbitol to fructose which requires $\mathrm{NAD}^{+}$as the hydrogen receptor. These observations suggest that the biochemical mechanism by which exogenous pyruvate prevents glucose-induced increases in vascular albumin permeation and blood flow may be mediated by normalization of the $\mathrm{NAD}^{+}: \mathrm{NADH}$ ratio and inhibition of de novo DAG synthesis.

Thus, the glucose-induced increase in DAG levels and its prevention by pyruvate in the present experiments are consistent with increased de novo synthesis of DAG and with the hypothesis that increased DAG levels and associated changes in PKC activity may modulate glucose-induced vascular functional changes. This hypothesis receives further support from the observations that $(a)$ a pharmacological inhibitor of protein kinase C (staurosporine) greatly attenuates the glucose-induced rise in microvascular albumin permeation; $(b)$ pharmacological activation of protein kinase $C$ with the phorbol ester TPA at physiological glucose levels mimics the effects of elevated glucose levels to increase microvascular albumin clearance and blood flow; $(c)$ pharmacological inhibition of the catabolism of endogenous DAG by the DAG kinase inhibitor MOG at physiological glucose concentrations also mimics glucose-induced increases in albumin clearance and blood flow; and $(d)$ prevention of the glucose-induced rise in DAG accumulation with 
pharmacological concentrations of pyruvate also prevents glucose-induced rises in microvascular albumin clearance and blood flow.

It is important to note that periodic instillation of agents into the skin chambers induces only a transient rise in the concentration of the agent which may nonetheless have longerlived effects. Elevated concentrations of glucose instilled into the chambers, for example, are known to be cleared from the chambers with a half-time of $\sim 1 \mathrm{~h}$ (16). The clearance of pharmacological agents also may occur fairly rapidly, and this likely accounts for the requirement for instillation of higher concentrations of such agents than employed for in vitro biochemical experiments. Accumulation of endogenous DAG induced by MOG is also likely transient, perhaps accounting for the inability to observe a MOG-induced rise in DAG levels, but may induce much longer-lived effects, such as activation and membrane association of protein kinase $C$ or phosphorylation of protein kinase $C$ substrates.

It is of interest that microvascular albumin clearance and blood flow are affected differently by pharmacological interventions directed at the modulation of protein kinase $C$ activity. TPA, for example, induced a rise in albumin clearance essentially identical to that observed with $30 \mathrm{mM}$ glucose, but the TPA-induced rise in blood flow was only about half that induced by $30 \mathrm{mM}$ glucose. Similarly, staurosporine completely prevented the rise in albumin clearance induced by 30 $\mathrm{mM}$ glucose or by MOG but had essentially no effect on the rise in blood flow induced by these agents. In addition, instillation of $30 \mathrm{mM}$ glucose into skin chambers for only $2 \mathrm{~d}$ induced a rise in blood flow, whereas tissue diacylglycerol content and microvascular albumin permeability were unaffected at that time. After $10 \mathrm{~d}$ of instillation, both tissue diacylglycerol content and microvascular albumin permeability rose by about threefold, but there was no further rise in blood flow. These observations suggest that changes in albumin clearance may be much more strongly regulated by protein kinase $C$ than changes in blood flow.

DAG accumulation may participate in the regulation of blood flow either through PKC activation or through non-protein kinase C-dependent mechanisms $(31-34)$, such as alteration in membrane physical properties $(35,36)$ or modulation of $\mathrm{Na}^{+}-\mathrm{K}^{+}$-ATPase activity $(37,38)$. Alternative explanations for the discrepancy in the effects of pharmacologic modulators of DAG levels and protein kinase $C$ activity must also be considered. It is likely that the increase in microvascular albumin clearance reflects alterations in albumin permeation across venular endothelium whereas increased blood flow reflects vasodilation of resistance arterioles. Thus the differential effects of pharmacological agents on blood flow and albumin clearance may be related to differences in local concentrations of drugs in and around the relatively thick-walled arterioles versus thin walled capillaries and venules and/or differences in permeation of these drugs into arteriolar smooth muscle cells versus capillary and venular endothelial cells.

It is also possible that the discordant effects of pharmacologic modulators of DAG levels and of protein kinase C activity on blood flow and microvascular albumin permeability in this model might reflect the participation of distinct isoenzymes of protein kinase $C$ in the regulation of these parameters (11). In addition, both TPA (33) and staurosporine (39) have been reported to exert some biologic actions that are not mediated by interaction with protein kinase $\mathrm{C}$.
In any case, the present studies attest to a potentially important role for glucose-induced increased de novo synthesis of DAG and activation of protein kinase $C$ in mediating glucoseinduced vascular functional changes. Although a similar role for alterations in DAG levels and protein kinase $C$ activity in the pathogenesis of other complications such as diabetic neuropathy seems plausible, evidence linking changes in DAG levels, protein kinase $\mathrm{C}$ activity, and associated changes in myoinositol levels and $\mathrm{Na}^{+}-\mathrm{K}^{+}$-ATPase activity is either lacking or controversial (40-42).

It is of interest that a role for protein kinase $\mathrm{C}$ similar to that suggested here in regulation of the permeability of endothelial cell layers to albumin has recently been proposed by others on the basis of findings with confluent monolayer cultures of bovine pulmonary artery endothelial cells (43). In that system, TPA increased protein kinase $C$ activity and transepithelial flux of ${ }^{125} \mathrm{I}$-albumin, and this effect was blocked by pharmacologic inhibitors of protein kinase $\mathrm{C}$. It may be that protein kinase $\mathrm{C}$ will prove to play a general role in the regulation of the permeability of endothelial cell layers to macromolecules.

In conclusion, our study provides new evidence for a link between glucose-induced increased DAG levels, activation of protein kinase $\mathrm{C}$, and microvascular functional changes in granulation tissue. These microvascular changes correspond to those observed in tissues of human diabetics. Our findings support the hypothesis that increased levels of DAG and associated changes in protein kinase $\mathrm{C}$ activity may participate in the cascade of biochemical imbalances that initiate the late vascular complications of diabetes.

\section{Acknowledgments}

We gratefully acknowledge the expert technical assistance of Eva Ostrow and Robert Seabold. Special thanks are due to Linda Dickey and to Jane Huth for preparation of the manuscript.

This work was supported in part by grants from the National Institutes of Health (RO1 DK 34388, KO4 DK 01553, EY 06600, HL 39934), the Juvenile Diabetes Foundation (grant No. 188471), the Council for Tobacco Research (grant No. 2364R1), the Diabetes Research and Training Center (DK 00579), and the Kilo Diabetes and Vascular Research Foundation.

\section{References}

1. Williamson, J. R., K. Chang, R. G. Tilton, C. Prater, J. Jeffrey, C. Weigel, W. R. Sherman, D. M. Eades, and C. Kilo. 1987. Increased vascular permeability in spontaneously diabetic BB/w rats and in rats with mild versus severe streptozotocin-induced diabetes: prevention by aldose reductase inhibitors and castration. Diabetes. 36:813-821.

2. Winegrad, A. I. 1987. Does a common mechanism induce the diverse complications of diabetes? Diabetes. 36:396-406.

3. Williamson, J. R., R. G. Tilton, K. Chang, and C. Kilo. 1988. Basement membrane abnormalities in diabetes mellitus: relationship to clinical microangiopathy. Diabetes Metab. Rev. 4:339-370.

4. Tilton, R. G., K. Chang G. Pugliese, D. M. Eades, M. A. Provine, W. R. Sherman, C. Kilo, and J. R. Williamson. 1989. Prevention of hemodynamic and vascular albumin filtration changes in diabetic rats by aldose reductase inhibitors. Diabetes. 38:1258-1270.

5. Marano, C. W., and F. M. Matschinsky. 1989. Biochemical manifestations of diabetes mellitus in microscopic layers of the cornea and retina. Diabetes Metab. Rev. 5:1-15.

6. Rustow, B., Y. Nakagawa, H. Rabe, G. Reichmann, D. Kunze, and K. Waku. 1984. Comparison of the HPLC-separated species patterns of phosphatidic acid, CDP-diacylglycerol and diacylglycerol synthesized de novo in rat liver microsomes. Biochim. Biophys. Acta. 961:364-369.

7. Farese, R. V., D. R. Cooper, T. S. Konda, G. Nair, M. L. Standaert, J. S. Davis, and R. J. Pollet. 1988. Mechanisms whereby insulin increases diacylglycerol in BC3H-1 myocytes. Biochem. J. 256:175-184. 
8. Dunlop, M. D., and R. G. Larkins. 1985. Pancreatic islets synthesize phospholipids de novo from glucose via acyldihydroxyacetone phosphate. Biochem. Biophys. Res. Commun. 132:467-173.

9. Peter-Riesch, B., M. Fahti, W. Schlegel, and C. B. Wollheim. 1988. Glucose and carbachol generate 1,2-diacylglycerols by different mechanisms in pancreatic islets. J. Clin. Invest. 81:1154-1161.

10. Wolf, B. A., R. A. Easom, M. L. McDaniel, and J. Turk. 1990. Diacylglycerol synthesis de novo from glucose by pancreatic islets isolated from rats and humans. J. Clin. Invest. 85:482-490.

11. Kikkawa, U., A. Kishimoto, and Y. Nishizuka. 1989. The protein kinase C family: heterogeneity and its implications. Annu. Rev. Biochem. 58:31-45.

12. Lee, T.-S., K. A. Saltsman, H. Ohashi, and G. L. King. 1989. Activation of protein kinase $\mathrm{C}$ by elevation of glucose concentration: proposal for a mechanism in the development of diabetic vascular complications. Proc. Natl. Acad. Sci. USA. 86:5141-5145.

13. Lee, T.-S., L. C. MacGregor, S. K. Fluharty, and G. L. King. 1989. Differential regulation of protein kinase $\mathrm{C}$ and $(\mathrm{Na}, \mathrm{K})$-adenosine trisphosphatase activities by elevated glucose levels in retinal capillary endothelial cells. J. Clin. Invest. 83:90-94.

14. Craven, P. A., and F. R. DeRubertis. 1989. Protein kinase $C$ is activated in glomeruli from streptozotocin diabetic rats. Possible mediation by glucose. $J$. Clin. Invest. 83:1667-1675.

15. Okumura, K., N. Akiyama, H. Hashimoto, K. Ogawa, and T. Satake. 1988. Alteration of 1,2-diacylglycerol content in myocardium from diabetic rats. Diabetes. 37:1168-1171

16. Williamson, J. R., E. Ostrow, D. Eades, K. Chang, W. Allison, C. Kilo, and W. R. Sherman. 1990. Glucose-induced vascular functional changes in nondiabetic rats: prevention by an aldose reductase inhibitor. J. Clin. Invest. 85:1167-1172.

17. Kilzer, P., K. Chang, J. Marvel, E. Rowold, P. Jaudes, S. Ullensvang, D. Kilo, and J. R. Williamson. 1985. Albumin permeation of new vessels is increased in diabetic rats. Diabetes. 34:333-336.

18. Lundberg, C., and B. Gerdin. 1984. The inflammatory reaction in an experimental model of open wound sin the rat. The effect of arachidonic acid metabolites. Eur. J. Pharmacol. 97:224-238.

19. Murtiashaw, M. H., J. W. Baynes, and S. R. Thorpe. 1983. Albumin catabolism in diabetic rats. Arch. Biochem. Biophys. 225:256-262.

20. Williamson, J. R., S. W. Holmberg, K. Chang, J. Marvel, S. P. Sutera, and P. Needleman. 1989. Mechanisms underlying atriopeptin-induced increases in hematocrit and vascular permeation in rats. Circ. Res. 64:890-899.

21. Tilton, R. G., G. Pugliese, K. Chang, C. Kilo, and J. R. Williamson. 1989. Effects of hypothyroidism on vascular ${ }^{125} \mathrm{I}$-albumin permeation and blood flow in rats. Metabolism. 38:471-478.

22. Preis, J. E., C. R. Loomis, R. M. Bell, and J. E. Niedel. 1987. Quantitative measurement of sn-1,2-diacylglycerol. Methods Enzymol. 141:294-300.

23. Wolf, B. A., R. A. Easom, J. H. Hughes, M. L. McDaniel, and J. Turk. 1989. Secretagogue-induced diacylglycerol accumulation in isolated pancreatic islets. Mass spectrometric characterization of the fatty acyl content indicates multiple mechanisms of generation. Biochemistry. 28:4291-4301.

24. Smith, P. K., R. I. Krohn, G. T. Hermanson, A. K. Mallia, F. H. Gartner, M. D. Provenzano, E. K. Fujimoto, N. M. Goeke, B. J. Olson, and D. C. Kleink 1985. Measurement of protein using bicinchoninic acid. Anal. Biochem. 150:7685 .

25. Eades, D. M., J. R. Williamson, and W. R. Sherman. 1989. Rapid analysis of sorbitol, galactitol, mannitol, and myo-inositol mixtures from biological sources. J. Chromatogr. 490:1-8.

26. Easom, R. A., J. H. Hughes, M. Landt, B. A. Wolf, J. Turk, and M. L. McDaniel. 1989. Comparison of effects of phorbol esters and glucose on protein kinase $C$ activation and insulin secretion in pancreatic islets. Biochem. $J .264 \cdot 27$ 33.

27. Tamaoki, T., H. Nomoto, I. Takaheshi, Y. Kalto, M. Norimato, and F. Tomita. 1986. Staurosporine. A potent inhibitor of phospholipid/Ca ${ }^{++}$dependent protein kinase. Biochem. Biophys. Res. Commun. 135:397-402.

28. Bishop, W. R., and R. M. Bell. 1986. 1-Mono-oleoyl-glycerol inhibits diacylglycerol kinase and augments agonist-induced diacylglycerol accumulation in platelets. J. Biol. Chem. 261:12513-12519.

29. Lou, M. F., J. E. Dickerson, R. Garadi, and B. M. York. 1988. Glutathione depletion in the lens of galactosemic and diabetic rats. Exp. Eye Res. 46:517530.

29a. Kawamura, T., S. Smith, and J. R. Williamson. 1990. Glucose-induced metabolic changes in tissue chamber granulation tissue. Diabetes. 39:192 (Abstr)

30. Travis, S. F., A. D. Morrison, R. S. Clements, A. I. Winegrad, and F. A Oski. 1971. Metabolic alterations in the human erythrocyte produced by increases in glucose concentration: the role of the polyol pathway. J. Clin. Invest. 50:2104-2112.

31. Ebanks, R., C. Roifman, A. Mellors, and G. B. Mills. 1989. The diacylglycerol analogue, 1,2-sn-dictaanoylglycerol, induces an increase in cytosolic free $\mathrm{Ca}^{++}$and cytosolic acidification of $\mathrm{T}$ lymphocytes through a protein kinase $\mathrm{C}$-independent process. Biochem. J. 258:689-698.

32. Liscovitch, M., B. Slack, J. Krysztof Blusztajn, and R. J. Wurtman. 1987. Differential regulation of phosphatidylcholine biosynthesis by 12-O-tetradecanoylphorbol-13-acetate and diacylglycerol in NG108-15 Neuroblastoma $\times$ glioma hybrid cells. J. Biol. Chem. 262:17487-17491.

33. Burch, R. M., A. L. Ma, and J. Axelrod. 1988. Phorbol esters and diacylglycerols amplify bradykinin-stimulated prostaglandin synthesis in Swiss 3T3 fibroblasts. Possible independence from protein kinase C. J. Biol. Chem. 263:4764-4767.

34. Kolesnick, R. N. 1987. 1,2-Diacylglycerols but not phorbol esters stimulate sphingomyelin hydrolysis in GH3 pituitary cells. J. Biol. Chem. 262:1675916762.

35. Epand, R. M. 1985. Diacylglycerols, lysolecithin, or hydrocarbons markedly alter the bilayer to hexagonal phase transition temperature of phosphatidylethanolamines. Biochemistry. 24:7092-7095.

36. de Boeck, H., and R. Zidovetzki. 1989. Effects of diacylglycerols on the structure of phosphatidylcholine bilayers: $\mathbf{a}^{2} \mathrm{H}$ and ${ }^{31} \mathrm{P}$ NMR study. Biochemistry. 28:7439-7466.

37. Smart, S. L., and R. C. Deth. 1988. Influence of $\alpha_{1}$-adrenergic receptor stimulation and phorbol esters on hepatic $\mathrm{Na}^{+} / \mathrm{K}^{+}$-ATPase activity. Pharmacology. (Basel). 37:94-104.

38. Bertorello, A., and A. Aperia. 1989. $\mathrm{Na}^{+}-\mathrm{K}^{+}$-ATPase is an effector protein for protein kinase $\mathrm{C}$ in renal proximal tubule cells. Am. J. Physiol. 256:F370F373.

39. Smith, C. D., J. F. Glickman, and K.-J. Chang. 1988. The antiproliferative effects of staurosporine are not exclusively mediated by inhibition of protein kinase C, Biochem. Biophys. Res. Commun. 156:1250-1256.

40. Lattimer, S. A., A. A. F. Sima, and D. A. Greene. 1989. In vitro correction of impaired $\mathrm{Na}^{+}-\mathrm{K}^{+}$-ATPase in diabetic nerve by protein kinase $\mathrm{C}$ agonists. $\mathrm{Am}$. J. Physiol. 256:E264-E269.

41. Simpson, D. M. F., and J. N. Hawthorne. 1988. Reduced $\mathrm{Na}^{+}-\mathrm{K}^{+}-\mathrm{ATPase}$ activity in peripheral nerve of streptozotozin-diabetic rats: a role for protein $\mathbf{k i}$ nase C? Diabetologia. 31:297-303.

42. Greene, D. A., S. A. Lattimer, and A. A. F Sima. 1988. Pathogenesis and prevention of diabetic neuropathy. Diabetes Metab. Rev. 4:201-221.

43. Lynch, J. L., T. J. Ferro, F. A. Blumenstock, A. M. Brockenauer, and A. B. Malik. 1990. Increased endothelial albumin permeability mediated by protein kinase C activation. J. Clin. Invest. 85:1991-1998. 